\title{
Extra-gonadal Sperm Reserve and Daily Sperm Production of Male Rabbits Fed Diets Supplemented with Cerium Oxide
}

\author{
Ladipo, M. Kudi \\ Department of Polymer and Textile Technology \\ Yaba College of Technology, Lagos, Nigeria
}

Sesan D. Oyefeso

Department of Animal Production and Health

Federal University of Technology, Akure, Nigeria

Olufemi A. Adu

Department of Animal Production and Health

Federal University of Technology, Akure, Nigeria

E-mail: oaadu@futa.edu.ng

Iyabo W. Akinmuyisitan

Department of Animal Science

Adekunle Ajasin University, Akungba-Akoko, Nigeria

Received: April 6, 2015 Accepted: April 21, 2015

doi:10.5296/jas.v3i2.7388 URL: http://dx.doi.org/10.5296/jas.v3i2.7388

\begin{abstract}
In an 8-week feeding experiment, 32 growing buck rabbits (Oryctolagus cuniculus) of an average weight of $1366.56 \pm 37.54 \mathrm{~g}$, were used to assess the effects of inclusion of different
\end{abstract}


dietary concentrations of Cerium oxide ( $\mathrm{CeO})$, a Rare Earth Element, at 0, 50, 100 and 150 ppm on fertility. The animals were randomly allotted to the four dietary groups, each consisting of eight animals per treatment. The Extra-gonadal Sperm Reserve (the sperm stored in the caput, corpus and cauda epididymis), the testes weights and the daily sperm production (DSP) were estimated. The results revealed that the extra-gonadal Sperm Reserves (ESR) were significantly $(\mathrm{P}<0.05)$ increased by dietary cerium oxide at $100 \mathrm{ppm}$ inclusion. Sperm reserves were higher in bucks fed dietary cerium oxide compared with those fed control diet and the highest value recorded at $100 \mathrm{ppm}$ level of inclusion. The results also showed that the testes weights and the daily sperm production (DSP) per testes of the buck rabbits were significantly $(\mathrm{P}<0.05)$ increased. The testes of the animals fed diets containing 50-150 ppm dietary cerium oxide had good and normal testicular generation and proper process of spermatogenesis. Therefore, feeding diets supplemented with cerium oxide to buck rabbits to be used for breeding would positively influence sperm production.

Keywords: Cerium oxide, Fertility, rabbits, Rare earth elements

\section{Introduction}

The ban of all antibiotic feed additives by the European Union in early 2006 necessitated a strong demand for new, efficient, safe and inexpensive feed additives which would better promote growth (Redling, 2006). Quite a number of feed additives are already known as replacements for antibiotics as feed additives but rare earth elements (REEs) might be the new generation of growth promoters.

Rare earth elements are the 15 lanthanide elements with atomic numbers 57 (lanthanum) through 71 (lutetium), which are in group III A of the periodic table. Chinese literature has reported amazing results achieved by supplying REE in animal diets (Redling, 2006).

The performance enhancement effects of REE supplemented diets could be achieved in a great variety of farm animals as well as in aquaculture (Xiong, 1995). It was reported that proper concentrations of REE in diet can improve animal growth performance without any form of interference with the quality of products (Adu, 2005, Redling, 2006 and Akinmuyisitan, 2015).

Moreover, it was reported that REE may also increase milk production in dairy cows and egg production in laying hens (Redling, 2006) and at the same time improved fertility in hens (Wu et al., 1994). However, based on the results obtained from Western countries feeding experiments, the effects of dietary REE vary with the animal species. Concentration and type of rare earths as well as the compositions of individual rare earth elements have also been shown to be important factors influencing performance enhancing effects of REE on animals (He et al., 2003; 2006; Redling, 2006). Also, it is generally agreed that the efficiency of growth- promoting agents highly correlates with keeping, housing, hygiene and feeding conditions (Wenk, 2004) as well as the genetic variations in animals. This might lead to differences in enzyme activities and keeping conditions, which may affect the composition of microbial populations within the gastrointestinal tract (Redling, 2006). Not only the effectiveness but also the safety of REE application has been assessed in China, prior to their 
commercial utilization (Wenk, 2004).

This study was designed to investigate the effects of different concentrations of dietary rare earth element (Cerium oxide) on the extra-gonadal sperm reserve and daily sperm production of male rabbits in male rabbits.

\section{Materials and Methods}

\subsection{Experimental Site and Animals}

The study was carried out at the Rabbit unit of the Teaching and Research Farm of the Federal University of Technology, Akure, Nigeria.

Thirty-two growing male rabbits of about 3 months old (12 weeks) of an average weight of $1366.56 \pm 37.54 \mathrm{~g}$ were used and individually housed in wire-meshed cages in an in-door pen and were fed ad libitum at 0800 and $1600 \mathrm{hr}$ for two weeks of physiological adjustment period. Kepromec Oral (Ivermectin ${ }^{\circledR}$ ) manufactured by Kepro, B.V. of Holland was administered through drinking water against potential ecto- and endo-parasites for two days at recommended dosage by the manufacturer before the commencement of the study. The procedures for the experiment was approved by the institution's animal care and use committee.

\subsection{Experimental Diets}

Four experimental diets were formulated: control (diet 1) with non-inclusion of REE, diets 2, 3 and 4 had 50, 100 and $150 \mathrm{ppm}$ inclusion of REE (Cerium oxide) respectively, as shown in Table 1. The animals were randomly assigned into one of the four diets (eight per treatment) after the 2 weeks of physiological adjustment period. The diets were isocaloric, isonitrogenous and satisfied the nutrient requirements of the animals as recommended by National Research Council (NRC, 1998). The bucks were provided with fresh, clean water and appropriate feed throughout the feeding period. 
Table 1. Gross composition (\%) of growing rabbit test diets

\begin{tabular}{|c|c|c|c|c|}
\hline & Diet 1 & Diet 2 & Diet 3 & Diet 4 \\
\hline Ingredients & Control & $50 \mathrm{mg} \mathrm{CeO}$ & $100 \mathrm{mg} \mathrm{CeO}$ & $150 \mathrm{mg} \mathrm{CeO}$ \\
\hline Maize & 32.10 & 32.10 & 32.10 & 32.10 \\
\hline Wheat offal & 41.80 & 41.80 & 41.80 & 41.80 \\
\hline Ground nut cake & 3.50 & 3.50 & 3.50 & 3.50 \\
\hline Palm kernel cake & 20.00 & 20.00 & 20.00 & 20.00 \\
\hline Oyster shell & 1.50 & 1.50 & 1.50 & 1.50 \\
\hline Bone meal & 0.25 & 0.25 & 0.25 & 0.25 \\
\hline Lysine & 0.15 & 0.15 & 0.15 & 0.15 \\
\hline Methionine & 0.05 & 0.05 & 0.05 & 0.05 \\
\hline Vitamin Premix & 0.20 & 0.20 & 0.20 & 0.20 \\
\hline Salt & 0.45 & 0.45 & 0.45 & 0.45 \\
\hline Cerium oxide (ppm) & - & 50 & 100 & 150 \\
\hline \multicolumn{5}{|c|}{ Calculated Nutrient } \\
\hline Crude Fibre (\%) & 10.83 & 10.83 & 10.83 & 10.83 \\
\hline Crude Protein (\%) & 10.38 & 10.38 & 10.38 & 10.38 \\
\hline ME* (MJ/kg) & 2906 & 2906 & 2906 & 2906 \\
\hline Ether Extract & 4.52 & 4.52 & 4.52 & 4.52 \\
\hline
\end{tabular}

ME*: Metabolisable Energy

\subsection{Determination of Testicular and Epididymal Sperm Reserve}

At puberty, all the experimental rabbits were slaughtered and their reproductive systems were carefully dissected, trimming off adhering tissues; the testes and the epididymis were carefully collected and weighed using a sensitive electronic balance. A portion of the right testes, whole left testes and the epididymis were homogenized and separated with a blender in $0.154 \mathrm{MNaCl}$ (physiological saline) at the rate of $10 \mathrm{ml} / \mathrm{g}$ testes. The suspensions were then mixed and sieved through a double layer of sterile gauze into clean glass test tubes and the sperm concentrations therein were determined by direct haemocytometric count after proper dilution (1:39, v/v) in $0.154 \mathrm{NaCl}$ (Egbunike et al., 1975; Adu and Egbunike, 2010).

\subsection{Estimation of Daily Sperm Production}

The daily sperm production (DSP) was estimated from the gonadal sperm reserves. The estimation of DSP from testicular homogenates is based on the fact that the nuclei of elongating spermatids are resistant to physical destruction at some point during spermatogenesis. The DSP of the bucks were calculated with the formula proposed by Amann (1970) as follows:

DSP $=\underline{\text { Testicularsperm count }}$

Time divisor (3.43)

Where 3.43 is a constant divisor for rabbit in calculating DSP (Adu and Egbunike, 2010) 
Statistical analyses

The design used for this experiment was Completely Randomized Design (CRD). Collected data were subjected to statistical analysis using ANOVA procedure of SAS (2008). The significant treatments were compared using Duncan's multiple range test of the same software.

\section{Results}

\subsection{Extra-Gonadal Sperm Reserve}

The extra-gonadal sperm reserve of bucks fed varied levels of dietary cerium oxide is as shown in Table 2. The testicular weight, epididymal weights and extra-gonadal sperm storage potentials of the rabbits were influenced $(\mathrm{P}<0.05)$ significantly in this study. The table showed that the extra-gonadal sperm reserves of the bucks were significantly $(\mathrm{P}<0.05)$ influenced by varied levels of dietary cerium oxide. It was observed that the sperm reserve in the left testes was higher than that of the right testes.

All the parameters determined were also significantly $(\mathrm{P}<0.05)$ influenced except the weight of the right cauda. Sperm reserves in the left, right and paired testes increased significantly $(\mathrm{P}<0.05)$ at $100 \mathrm{ppm}$ level of inclusion (diets 3). The values ranged between 1.37-1.70/g for the right testis, $1.57-1.78 / \mathrm{g}$ for the left testis and $2.94-3.48 / \mathrm{g}$ for the paired testis as against $1.35,1.43$ and $2.78 / \mathrm{g}$ in control diet for the right, left and paired testis respectively. For the right and total caput sperm reserve, there was significant improvement with the values ranging between $1.92-2.11 \times 10^{9}$ for the right caput, $3.98-4.45 \times 10^{9}$ for total caput compared with 1.76 and $3.71 \times 10^{9}$ in control diets for the right and total caput respectively and the highest values observed at $100 \mathrm{ppm}$ level of cerium oxide inclusion. For the left caput, the level of significance was at 100 and 150 ppm levels of inclusion with the values 2.34 and $2.19 \times 10^{9}$, respectively compared with $1.95 \times 10^{9}$ for control diet.

The sperm reserve in the corpus was significantly influenced and the values ranged between $3.44-3.97 \times 10^{9}$ for the left corpus, $6.64-7.67 \times 10^{9}$ for total corpus as against 3.47 and $6.76 \times 10^{9}$ in control diets for the left and total corpus respectively; the level of significance was also at $100 \mathrm{ppm}$ level of cerium oxide inclusion (diet 3) while that of the right corpus ranged from $3.20-3.70 \times 10^{9}$ and the highest value was observed at $100 \mathrm{ppm}$ level of cerium oxide inclusion.

The cauda sperm reserve was similar across the dietary treatments and the highest values were at $100 \mathrm{ppm}$ level of cerium oxide inclusion. The total epididymal weight was significantly $(\mathrm{P}<0.05)$ higher in bucks fed 100 ppm dietary cerium oxide (diets 3 ) compared with the control diet.

It was observed that the sperm reserves were higher in bucks fed dietary cerium oxide compared with those fed control diet and the highest value recorded at $100 \mathrm{ppm}$ level of inclusion of dietary cerium oxide throughout, in all the parameters determined. 
Table 2. Extra-Gonadal sperm reserve $\left(\times 10^{9}\right)$ of bucks fed dietary cerium oxide

\begin{tabular}{|c|c|c|c|c|c|}
\hline & Diet 1 & Diet 2 & Diet 3 & Diet 4 & \multirow{2}{*}{ \pm SEM } \\
\cline { 1 - 4 } Parameters & Control & $50 \mathrm{ppm}^{\mathrm{n}}$ & $100 \mathrm{ppm}$ & $150 \mathrm{ppm}$ & \\
\hline Right (/g testis) & $1.35^{\mathrm{b}}$ & $1.42^{\mathrm{b}}$ & $1.70^{\mathrm{a}}$ & $1.37^{\mathrm{b}}$ & \multirow{2}{*}{0.12} \\
\hline Left (/g testis) & $1.43^{\mathrm{b}}$ & $1.61^{\mathrm{a}}$ & $1.78^{\mathrm{a}}$ & $1.57^{\mathrm{ab}}$ & 0.19 \\
\hline Paired (/g testis) & $2.78^{\mathrm{b}}$ & $3.03^{\mathrm{b}}$ & $3.48^{\mathrm{a}}$ & $2.94^{\mathrm{b}}$ & 0.29 \\
\hline Right (/testis) & $2.17^{\mathrm{c}}$ & $2.57^{\mathrm{ab}}$ & $2.74^{\mathrm{a}}$ & $2.39^{\mathrm{b}}$ & 0.14 \\
\hline Left (/testis) & $2.41^{\mathrm{b}}$ & $2.69^{\mathrm{a}}$ & $2.83^{\mathrm{a}}$ & $2.58^{\mathrm{ab}}$ & 0.16 \\
\hline Paired (/testis) & $4.61^{\mathrm{c}}$ & $5.26^{\mathrm{ab}}$ & $5.57^{\mathrm{a}}$ & $4.97^{\mathrm{bc}}$ & 0.27 \\
\hline Right caput & $1.76^{\mathrm{c}}$ & $1.94^{\mathrm{b}}$ & $2.11^{\mathrm{a}}$ & $1.92^{\mathrm{b}}$ & 0.09 \\
\hline Left caput & $1.95^{\mathrm{b}}$ & $2.04^{\mathrm{b}}$ & $2.34^{\mathrm{a}}$ & $2.19^{\mathrm{a}}$ & 0.10 \\
\hline Total caput & $3.71^{\mathrm{c}}$ & $3.98^{\mathrm{b}}$ & $4.45^{\mathrm{a}}$ & $4.11^{\mathrm{b}}$ & 0.17 \\
\hline Right corpus & $3.29^{\mathrm{b}}$ & $3.63^{\mathrm{a}}$ & $3.70^{\mathrm{a}}$ & $3.20^{\mathrm{b}}$ & 0.15 \\
\hline Left corpus & $3.47^{\mathrm{b}}$ & $3.57^{\mathrm{b}}$ & $3.97^{\mathrm{a}}$ & $3.44^{\mathrm{b}}$ & 0.23 \\
\hline Total corpus & $6.76^{\mathrm{bc}}$ & $7.20^{\mathrm{b}}$ & $7.67^{\mathrm{a}}$ & $6.64^{\mathrm{c}}$ & 0.29 \\
\hline Right cauda & 2.29 & 2.47 & 2.60 & 2.25 & 0.22 \\
\hline Left cauda & $2.57^{\mathrm{ab}}$ & $2.76^{\mathrm{ab}}$ & $2.91^{\mathrm{a}}$ & $2.48^{\mathrm{b}}$ & 0.24 \\
\hline Total cauda & $4.86^{\mathrm{ab}}$ & $5.23^{\mathrm{ab}}$ & $5.51^{\mathrm{a}}$ & $4.74^{\mathrm{b}}$ & 0.46 \\
\hline Total epididymal & $15.33^{\mathrm{b}}$ & $16.40^{\mathrm{ab}}$ & $17.63^{\mathrm{a}}$ & $15.49^{\mathrm{ab}}$ & 0.56 \\
\hline
\end{tabular}

abc: Means on same row with different superscripts differ significantly $(\mathrm{P}<0.05)$

SEM- Standard Error of Mean

\subsection{Testicular Weights and the Daily Sperm Production}

Table 3 shows the testicular weights and the daily sperm production (DSP) of buck rabbits fed varied levels of dietary cerium oxide. The testicular weights (right and paired testes) increased $(\mathrm{P}<0.05)$ significantly at $50 \mathrm{ppm}$ concentration of cerium oxide compared with the control diet except that of the left testis that was not influenced $(\mathrm{P}>0.05)$ significantly. The weights of the right and paired testes of buck rabbits fed dietary cerium oxide were higher than the control and the weights of the right testes ranged between 1.86-2.23 $\mathrm{g}$ across the dietary treatment as against $1.81 \mathrm{~g}$ for control diet while the weights of the paired testes ranged from $4.00-4.67 \mathrm{~g}$ for diets $2-4$ compared with $3.89 \mathrm{~g}$ for control diet.

The results also showed that DSP per testes of the buck rabbits were significantly $(\mathrm{P}<0.05)$ increased at $100 \mathrm{ppm}$ level of inclusion of cerium oxide. The daily sperm production in the right testis ranged from $0.41-0.51\left(\times 10^{7}\right), 0.47-0.53\left(\times 10^{7}\right)$ for the left testis and $0.87-1.03$ $\left(\times 10^{7}\right)$ for the paired testis compared with $0.40,0.42$ and $0.82\left(\times 10^{7}\right)$ for the control diet respectively. 
Table 3. Daily sperm production of bucks fed varied levels of dietary cerium oxide

\begin{tabular}{|c|c|c|c|c|c|}
\hline & Diet 1 & Diet 2 & Diet 3 & Diet 4 & \multirow{2}{*}{} \\
\cline { 1 - 4 } Parameters & Control & $50 \mathrm{ppm}$ & $100 \mathrm{ppm}$ & $150 \mathrm{ppm}$ & \multirow{2}{*}{ SEM } \\
\hline Weight $(\boldsymbol{g})$ & & & & & \\
\hline Left testis & 2.09 & 2.44 & 2.12 & 2.14 & 0.22 \\
\hline Right testis & $1.81^{\mathrm{b}}$ & $2.23^{\mathrm{a}}$ & $1.90^{\mathrm{ab}}$ & $1.86^{\mathrm{ab}}$ & 0.24 \\
\hline Paired testis & $3.89^{\mathrm{b}}$ & $4.67^{\mathrm{a}}$ & $4.01^{\mathrm{ab}}$ & $4.00^{\mathrm{ab}}$ & 0.45 \\
\hline Daily Sperm Production & & & & & \\
\hline Right $\left(\times 10^{7} / \mathrm{g}\right.$ testis) & $0.40^{\mathrm{b}}$ & $0.42^{\mathrm{b}}$ & $0.51^{\mathrm{a}}$ & $0.41^{\mathrm{b}}$ & 0.03 \\
\hline Left (x10/g testis) & $0.42^{\mathrm{b}}$ & $0.48^{\mathrm{ab}}$ & $0.53^{\mathrm{a}}$ & $0.47^{\mathrm{ab}}$ & 0.06 \\
\hline Paired (x10/g testis) & $0.82^{\mathrm{b}}$ & $0.90^{\mathrm{b}}$ & $1.03^{\mathrm{a}}$ & $0.87^{\mathrm{b}}$ & 0.09 \\
\hline Right (x109/testis) & $0.64^{\mathrm{c}}$ & $0.76^{\mathrm{ab}}$ & $0.81^{\mathrm{a}}$ & $0.71^{\mathrm{b}}$ & 0.04 \\
\hline Left (x10/testis) & $0.72^{\mathrm{b}}$ & $0.80^{\mathrm{a}}$ & $0.84^{\mathrm{a}}$ & $0.76^{\mathrm{ab}}$ & 0.05 \\
\hline Paired (x10/testis) & $1.36^{\mathrm{c}}$ & $1.56^{\mathrm{ab}}$ & $1.65^{\mathrm{a}}$ & $1.47^{\mathrm{bc}}$ & 0.08 \\
\hline
\end{tabular}

abc: Means on same row with different superscripts differ significantly $(\mathrm{P}<0.05)$

SEM- Standard Error of Mean

\section{Discussion}

The result of this study is in line with the report of Wu et al. (1994) that reported an improvement in fertility of hens fed dietary REEs and Shao et al. (1998) that reported that REE had significant positive effect on embryo development of carp. This is an indication of possible interaction of dietary rare earth element with the hormones of reproduction. The increase in testes weight observed in this study confirms the possible impacts of REE on sperm production. This is line with the assumptions of Amman (1970) and Møller (1989) that increase in relative testis size reflects increased investment in sperm production, since there is evidence of correlation between testis size and the number of sperm produced per unit time and the report of Møller (1989) that testicle size is a good indication of sperm producing ability. Gage and Freckleton (2003) also described the mammalian testes as infallible predictors of spermatozoa production. The increase in DSP observed in rabbits fed diets 2, 3, and 4 over the control diet is an indication that cerium oxide influenced spermatogenesis positively. This is a pointer to possible effects of REE on hormones primarily involved in sperm production such as the follicle stimulating hormones, luteinizing hormone and testosterone.

ESR represents the sperm stored in the caput, corpus and cauda epididymis. Egbunike and Elemo (1978) reported a close relationship between organ weight and sperm reserve. The significantly higher ESR and the testicular weights of the rabbits fed diets supplemented with cerium oxide may be attributed to the influence of dietary cerium oxide on sperm production in rabbits, as sperm production and storage are related (Egbunike and Elemo, 1978).

It can be concluded that dietary REE is capable of enhancing fertility in rabbits by significantly increasing the extra-gonadal sperm reserve as well as the daily sperm production at $100 \mathrm{ppm}$ and testes weight at $50 \mathrm{ppm}$. Ji et al. (1985) found no increase in chromosome abberation rates 
of marrow cells after oral application, but, when compared to low doses at high doses, chromosomal translocation of the spermatocytes increased significantly.

This study revealed that the testes of animals fed diets containing 50-150 ppm cerium oxide have good and normal testicular generation and proper process of spermatogenesis.

Therefore, this study has clearly demonstrated that feeding diets supplemented with cerium oxide to buck rabbits to be used for breeding would positively influence sperm production.

\section{References}

Adu, O. A. (2005). Performance enhancing effect of Rare Earth Elements in growing rabbits. Tropical Animal Production Investigations, 7 (1): 93-98

Adu, O. A. \& Egbunike, G. N. (2005). Spermatogenesis and daily sperm production of rabbits fed diets with different levels of copper sulphate. Journal of Agriculture, Forestry and Social Sciences, 3(2), 126-131.

Adu, O. A. \& Egbunike, G. N. (2010). Semen quality, Fertility and Reproductive organ weights of pubertal Boars fed dietary copper. Journal of Applied Agricultural Research. 2, 61-67.

Akinmuyisitan, I. W., Gbore, F. A., \& Adu, O. A. (2015). Reproductive Performance of Growing Female Rabbits (Oryctolagus Cuniculus) fed diets supplemented with Cerium Oxide. Journal of Medical and Bioengineering. 4 (3), pp. 239-243

Amann, R. P. (1970). Sperm production rates. In The testis, vol. 1 (eds Johnson A. D., Gomes W. R., Vandemark N. L.), pp. 433-482. New York, NY: Academic Press. http://dx.doi.org/10.1016/b978-0-12-386601-1.50013-5

Egbunike, G. N., Holtz, W., \& Smidt, D. (1975). Reproductive capacity of German improve boars. Gonadal and extra-gonadal sperm reserves. Zuchthygiene. 10:184-191. http://dx.doi.org/10.1111/j.1439-0531.1975.tb00301.x

Egbunike, G. N., \& Elemo, A. O. (1978). Testicular and epididymal sperm reserves of crossbreed European boars raised and maintained in the humid tropics .J. reprod. Fert. 54. 245-248.

Gage M. J. G., \& Freckleton, R. P. (2003). Relative testis size and sperm morphometry across mammals: no evidence for an association between sperm competition and sperm length. Proc. R. Soc. Lond. B 270, 625-632. http://dx.doi.org/10.1098/rspb.2002.2258

Ji Y, Cui M, Wang Y., \& Zhang X (1985). Toxicological study on safety evaluation of rare earth elements used in agriculture. In Xu G and Xiao J. (Eds.) New frontiers in rare earth science and applications. Proceedings of the 1st International conference on rare earth development and applications. Beijing, September 10-14. pp. 700-704, Science Press, Beijing

He, M. L., Wang, Y. Z., Xu, Z. R., Chen, M. L., \& Rambeck, W. A. (2003). Effect of dietary rare earth elements on growth performance and blood parameters of rats. Journal of Animal Physiology and Animal Nutrition, 87, 229-235. 
He, M. L., Wehr, U., \& Rambeck, W. A. (2006). Oral administration of a low dose of rare earth elements improved the performance of broilers. J. Anim Phys. Anim. Nutr. 153-243. http://dx.doi.org/10.1046/j.1439-0396.2003.00432.x

Møller, A. P. (1989). Ejaculate quality, testes size and sperm production in mammals. Funct. Ecol. 3, 91-96. http://dx.doi.org/10.2307/2389679

National Reasearch Council, (1998). Nutrient requirements of domestic animals. In: Nutrient requirements of rabbits ( $\left.9^{\text {th }} \mathrm{Ed}\right)$. National Academy of Sciences. Washington. DC.

Redling, K. (2006). Rare earth elements in agriculture with emphasis on animal husbandry. Diss. Ludwig-Maximilians-Universität, München.

SAS Institute Inc. (2008). SAS / STAT User's Guide.Version 9.2 for Windows.SAS InstituteInc; SAS Campus Drive. Carry, North Carolina, U.S.A.

Shao, H., Liu, H., Jiang, Z., Zong, Z. \& Liu, W. (1998). Effect of Rare Earth Elements on egg embryo development of carp. Fresh Water Fishery, 28(4), 20-21

Wenk, C. (2004). Erwartungen und Möglichkeiten von Pflanzenextrakten in der Schweineernährung. In Schweinehaltung, 04.255, Sursee/Oberkirch, Schweiz. pp. 24

Wu, J., Zhang, Z., \& Yan, J. (1994) An initial study on effect of adding rare earth element on productivity of egg laying breeder hens,'Ning Xia Sci. Technol. Farming Forest, 4. 36-38.

Xiong, B. K. (1995). Application of Rare Earths in Chinese Agriculture and their perspectives of Development. In Proceeding of the Rare Earths in Agriculture Seminar, 20. September, pages 5-9, Canberra, ACT Australia.

\section{Copyright Disclaimer}

Copyright for this article is retained by the author(s), with first publication rights granted to the journal.

This is an open-access article distributed under the terms and conditions of the Creative Commons Attribution license (http://creativecommons.org/licenses/by/3.0/). 